\title{
Assessment of the Water Quality Characteristics of Kaduna River Receiving Wastewater Discharges
}

\author{
Garba H. ${ }^{1 *}$ and Elanu C. A. ${ }^{2}$ \\ ${ }^{1,2}$ Department of Civil Engineering, Nigerian Defense Academy, Kaduna, Nigeria \\ Corresponding Author: *garbaharuna84@ gmail.com
}

\begin{abstract}
An assessment of the chemical characteristics of industrial and domestic wastewater discharges on seven parameters into Kaduna River on a bimonthly basis was carried out. $\mathrm{PH}$, dissolved oxygen $(D O)$, chloride, nitrite, chemical oxygen demand (COD), biochemical oxygen demand (BOD) and iron were analyzed to determine their concentration levels. From the analysis, the highest mean concentration of the parameters were $8.24 \mathrm{of} \mathrm{pH,} 7.7 \mathrm{mg} / \mathrm{l}$ of $\mathrm{DO}, 233.4 \mathrm{mg} / \mathrm{l}$ of chloride, 55.68 $\mathrm{mg} / \mathrm{l}$ of COD, $27.95 \mathrm{mg} / \mathrm{l}$ of nitrite, $122.22 \mathrm{mg} / \mathrm{l}$ of $\mathrm{BOD}$, and $17.05 \mathrm{mg} / \mathrm{l}$ of iron. After comparing with prescribed standards, it can be concluded that there is evidence of organic and inorganic accumulation of contaminants into River Kaduna.
\end{abstract}

Keywords: Chemical, Wastewater, Discharges, Concentration, Effluent

\subsection{Introduction}

Since Nigerian independence in 1960, there has been concerted effort to exploit the nation's various resources to meet various human needs. This has led to rapid technological development and industrialization. Industrialization has been concentrated in the urban cities and at such locations where the absorptive capacities of the natural environment can be easily exhausted. This practice according to Beecroft (1986) leads to serious degradation of the environmental resources of the area. Beecroft (1986) reported that about $80 \%$ of major industries in Nigeria are concentrated in Port Harcourt, Kano, Lagos and Kaduna. Ludwig and Gould (1988) observed that the disposal of various waste materials into marine waters is not a modern phenomenon.

Industrial wastewater according to Hanchang (2013) is one of the important sources in the pollution of water environment. During the last century a huge amount of industrial wastewater was discharged into rivers, lakes and coastal areas. This resulted in serious pollution problems in water environment and caused negative effects to the eco-system and human's life. The practice according to Islam and Tanaka (2004) has being used as a preferred disposal option since the beginning of modern civilization. Beecroft (1986), further identified that the physical, chemical and biological composition of the effluent waste discharges into Kaduna river indicate that effluent from textile industry are characterized by high concentration of Chemical Oxygen Demand (COD), Biological Oxygen Demand (BOD), and colour. The food and beverages industry discharges according to Beecroft (1986) have high BOD, COD and solid waste; while the petrochemical effluent have high level of oil and grease, COD and a low BOD.

According to a report by the Kaduna State Environmental Protection Agency (KEPA) (2002), the industries in Kaduna discharge over $500 \mathrm{~m}^{3} / \mathrm{d}$ of untreated effluent into the Kaduna River. This has led to massive pollution of both surface and groundwater resources. Awale and Soubaneh (2004) observed that the world's chemical industries face formidable environmental regulatory challenges in treating their wastewater effluent. Various industrial wastewater treatment technologies currently available include physico-chemical and biological processes as well as constructed wetlands and conventional or advanced oxidation processes. Furthermore, Garba (2007) investigated the 
effectiveness of immobilized cells of $F$ oxysporium in the treatment of textile effluent as well as biosorption of heavy metals from textile wastewater discharged into Kaduna River.

Kaduna metropolis is one of the few industrialized cities in Nigeria with over ninety two (92) industries out of which twenty seven are classified as wet effluent discharges. The aim of this study is to assess the chemical concentrations of seven parameters of industrial and domestic wastewater discharges on a bimonthly basis as evidence of inorganic and organic pollutant accumulation in River Kaduna.

\subsection{Study area}

This study is focused on River Kaduna which takes its source from Sherri Hill in Plateau State. River Kaduna flows north-west towards the Kaduna metropolis and thereafter takes a south west direction at Mureji. River Kaduna covers a total distance of $540 \mathrm{~km}$ from source to mouth (Folorunsho, 2000). The drainage basin for this study is approximately 18,277.83 km2. Kaduna State which occupies a central position in the northern geographical region of Nigeria lies within the Northern Savannah Zone of Nigeria with an absolute location of Latitude $9^{\circ} 30^{\prime} \mathrm{N}$ to $11^{\circ} 45^{\prime} \mathrm{N}$ and Longitude $7^{\circ} \mathrm{E}$ to $8^{\circ} 30^{\prime} \mathrm{E}$. It covers a total land mass of $2,896,000 \mathrm{~km}^{2}$. The topography is that of undulating plateau, as shown in Figure 1.

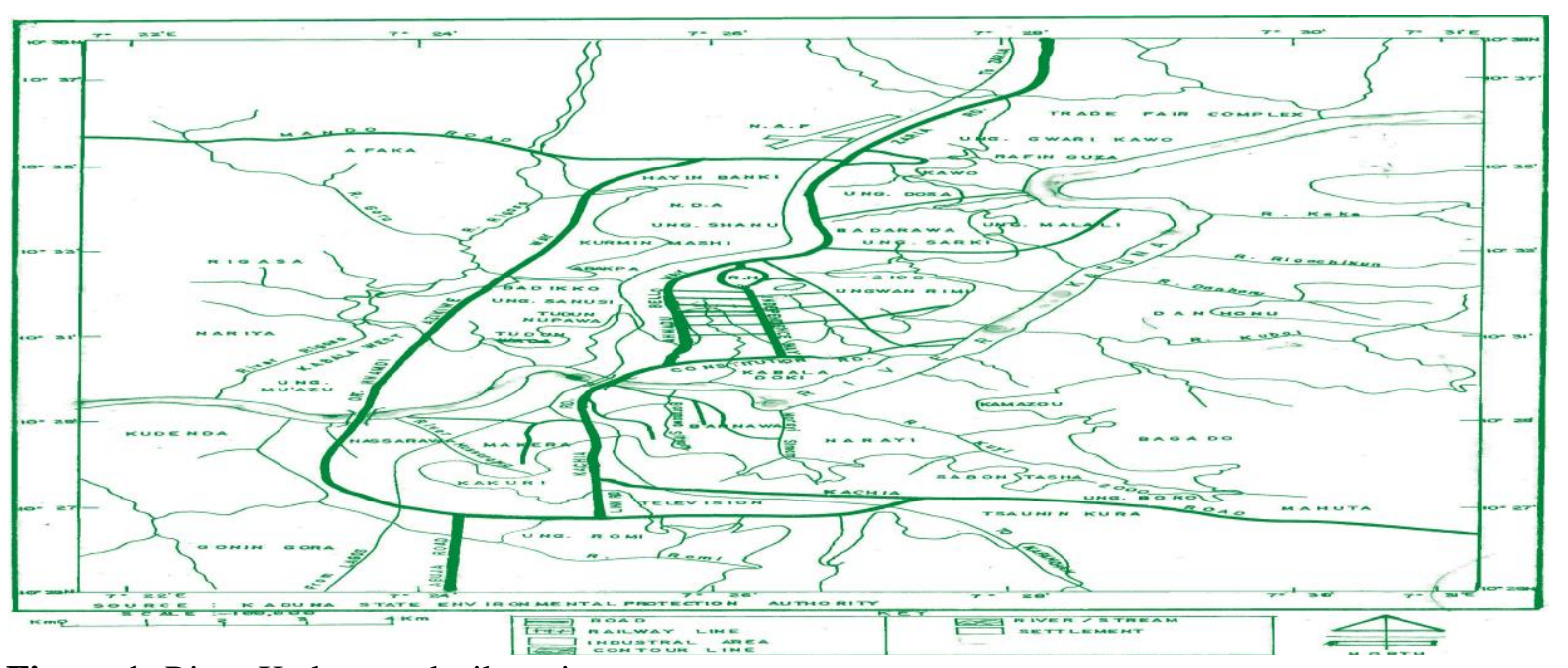

Figure 1: River Kaduna and tributaries

(Source: Kaduna State Environmental Protection Authority)

\subsection{Climate}

Kaduna State has two distinct seasons. The dry season last from November to mid-April while the rainy season which is cool last between 5-6 months starting from mid-April. The State extends from the tropical grassland known as Guinea Savannah to Sudan Savannah. The vegetation is thick and grasses about 3.6 metre tall with big trees which grow shorter towards the Sudan Savannah.

\subsection{Materials and Methods}

In this study, the concentration of chemical effluents from selected industries in Kaduna South as well as point discharges from domestic sources with abbreviations as shown in Figure 2 are as follows: Kabala West drain (KW), Unguwar Muazu domestic drain (UM), Kudenda village domestic drain (KV), Kaduna Polytechnic farms (KPF), Rigasa domestic drain(RGDD), Rafin drain (RD), Romi drain (RMD), River Kaduna bye pass bridge (RKBB), Kakuri domestic and industrial drain (KD), Makera drain (MD), Nasarawa domestic drain (NDD), Kaduna South water works (KSWW) and Kaduna North water works (KNWW). The locations of the points are as indicated in Figure 2 and the selection of these points was based on the location of the industries and domestic discharge outlets. 


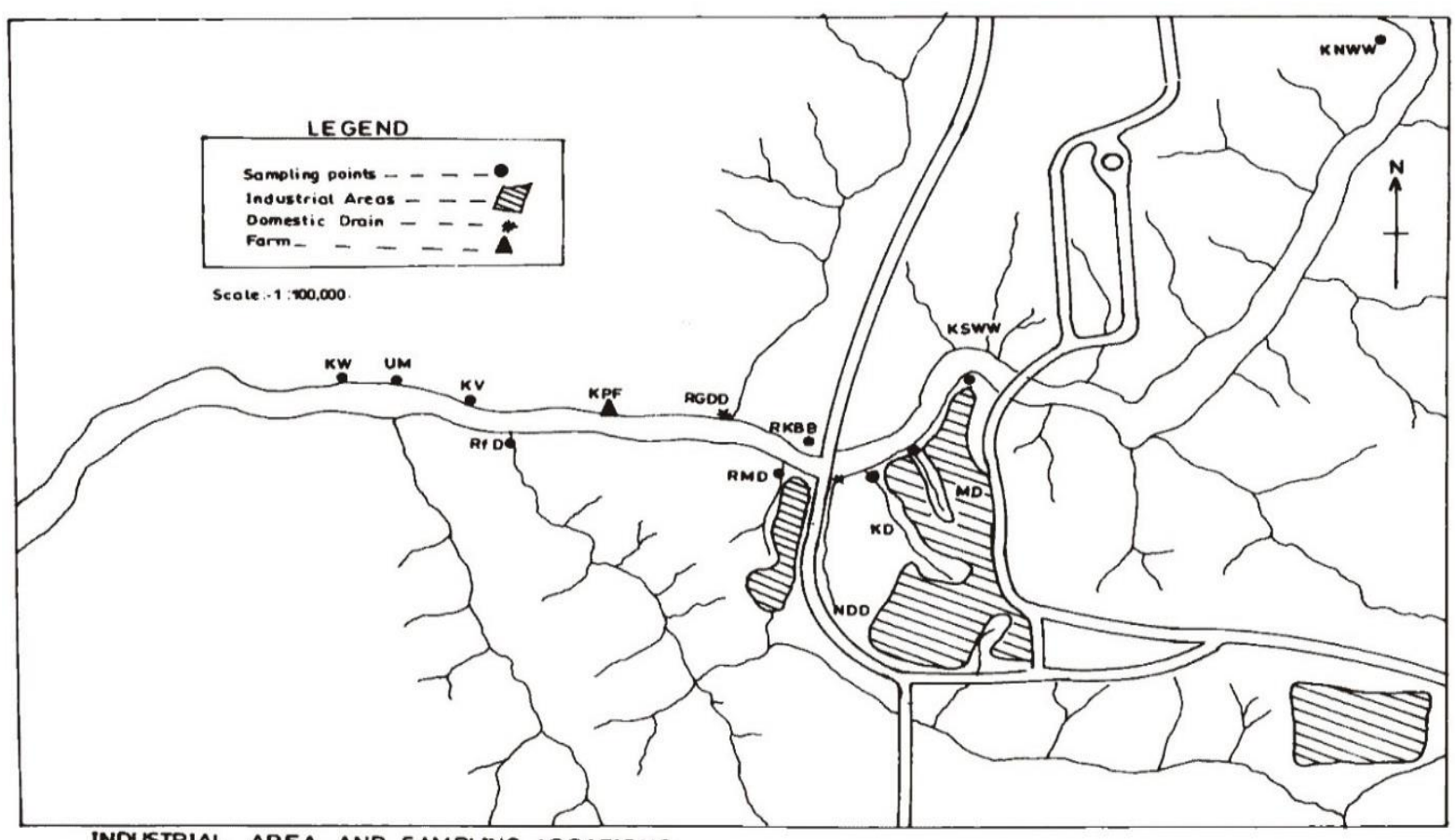

INDUSTRIAL AREA AND SAMPLING LOCATIONS.

Figure 2: Sampling locations

The parameters were analyzed to ascertain their pollution levels at the point of discharge into the Kaduna River. The characteristics of the chemicals were compared to standards established by World Health Organization (WHO), Federal Environmental Protection Agency (FEPA), National Environmental Standards Regulation Enforcement Agency (NESREA) and the United States Environmental Protection Agency. However, some of the characteristics are within the standards specified above while some indicates that over time there will be pollution. The regulation limitations from the standards are as follows: $\mathrm{pH}(\mathrm{NESREA} / \mathrm{FEPA}=6.0, \mathrm{WHO}=5-9)$; COD $($ NESREA/FEPA $=80 \mathrm{mg} / \mathrm{l}$ for agricultural chemicals, $15 \mathrm{mg} / \mathrm{l}$ for dyestuff and dye intermediate; WHO $=40 \mathrm{mg} / \mathrm{l}$ ); BOD (NESREA/FEPA $=30 \mathrm{mg} / \mathrm{l}$ for agricultural chemicals, $15 \mathrm{mg} / \mathrm{l}$ for dye stuff and dye intermediates, $15 \mathrm{mg} / \mathrm{l}$ for food processing; WHO $=40 \mathrm{mg} / \mathrm{l}$ ); Nitrites (NESREA/FEPA $=20 \mathrm{mg} / \mathrm{l}$ for agricultural chemicals, WHO $=10 \mathrm{mg} / \mathrm{l}$ ); Iron (NESREA/FEPA $=20 \mathrm{mg} / \mathrm{l}, \mathrm{WHO}=2 \mathrm{mg} / \mathrm{l}$ ).

The procedure for sampling involves dipping a transparent plastic container downwards below the surface of the water to about $300 \mathrm{~mm}$, and allowing the container to be filled, two times every month from January to December. The following parameters: $\mathrm{pH}$, chloride, nitrite, Chemical Oxygen Demand (COD), Biochemical Oxygen Demand (BOD) and Iron were analyzed based on the Standard Procedure for the examination of waters and wastewater by Arnold et al. (1992).

\subsection{Results and Discussion}

\subsection{Results}

The results are presented in Figures $3-9$. The typical characteristics of the discharges due to different sources identified as follows: dissolved oxygen obtained from domestic wastewater discharges at $\mathrm{KW}$, $\mathrm{UM}, \mathrm{KV}, \mathrm{RKBB}, \mathrm{KD}$ and NDD; $\mathrm{pH}$ obtained from KNWW and KSWW; nitrites obtained from NDD, RFD, RKBB and KDF; BOD obtained from KW, UM, KV, RKBB and KD; COD obtained from RM and $\mathrm{KV}$; iron obtained from KD and MD; and Chlorites obtained from MD, RFD and UM drains. 


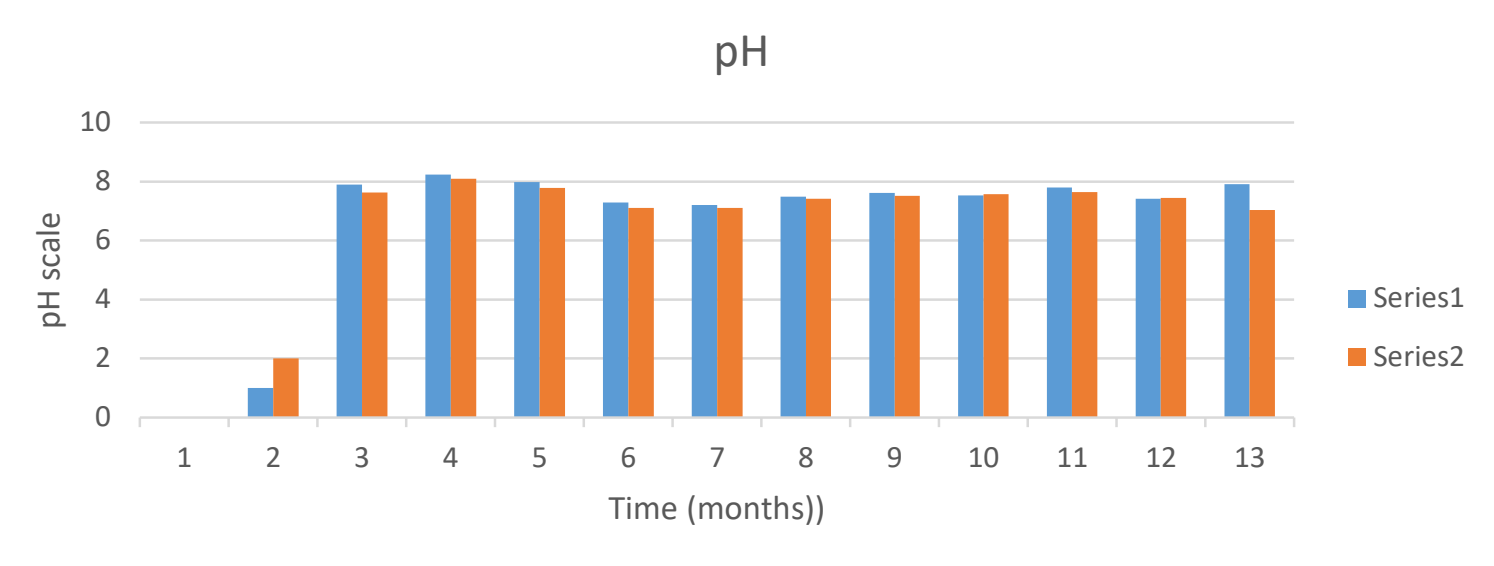

Figure 3: Monthly $\mathrm{pH}$ discharge concentration

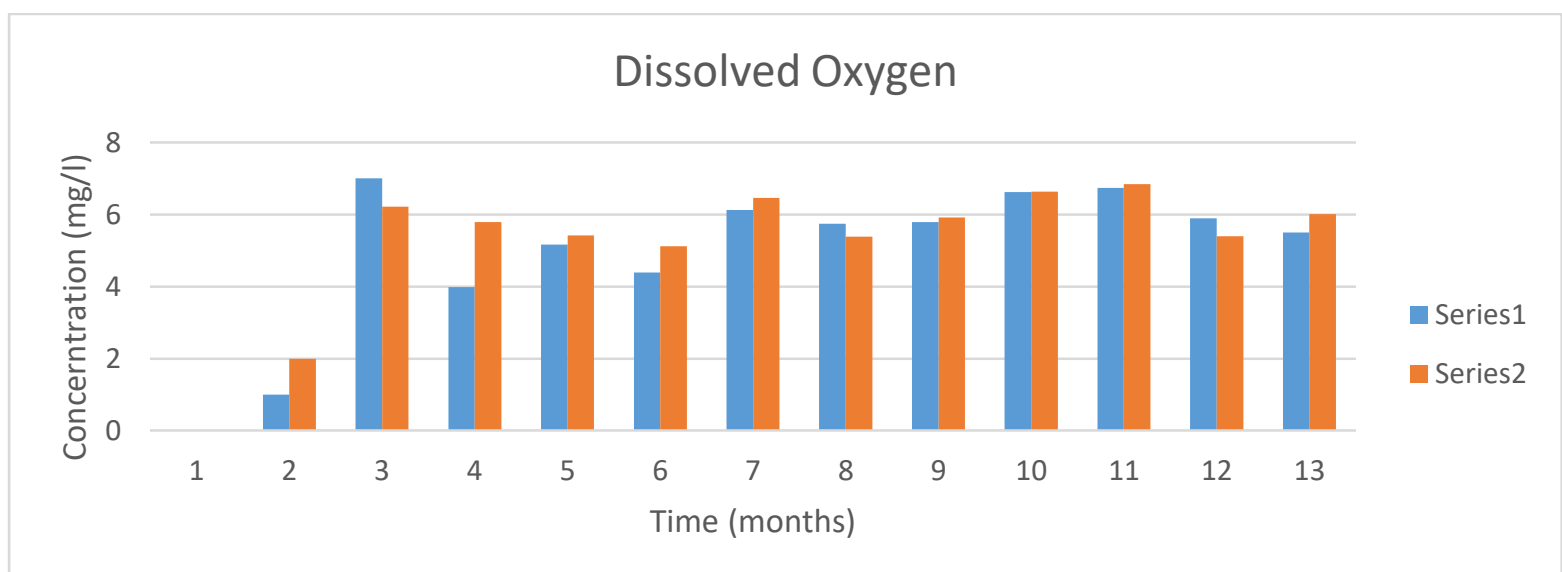

Figure 4: Monthly dissolved oxygen discharge concentration

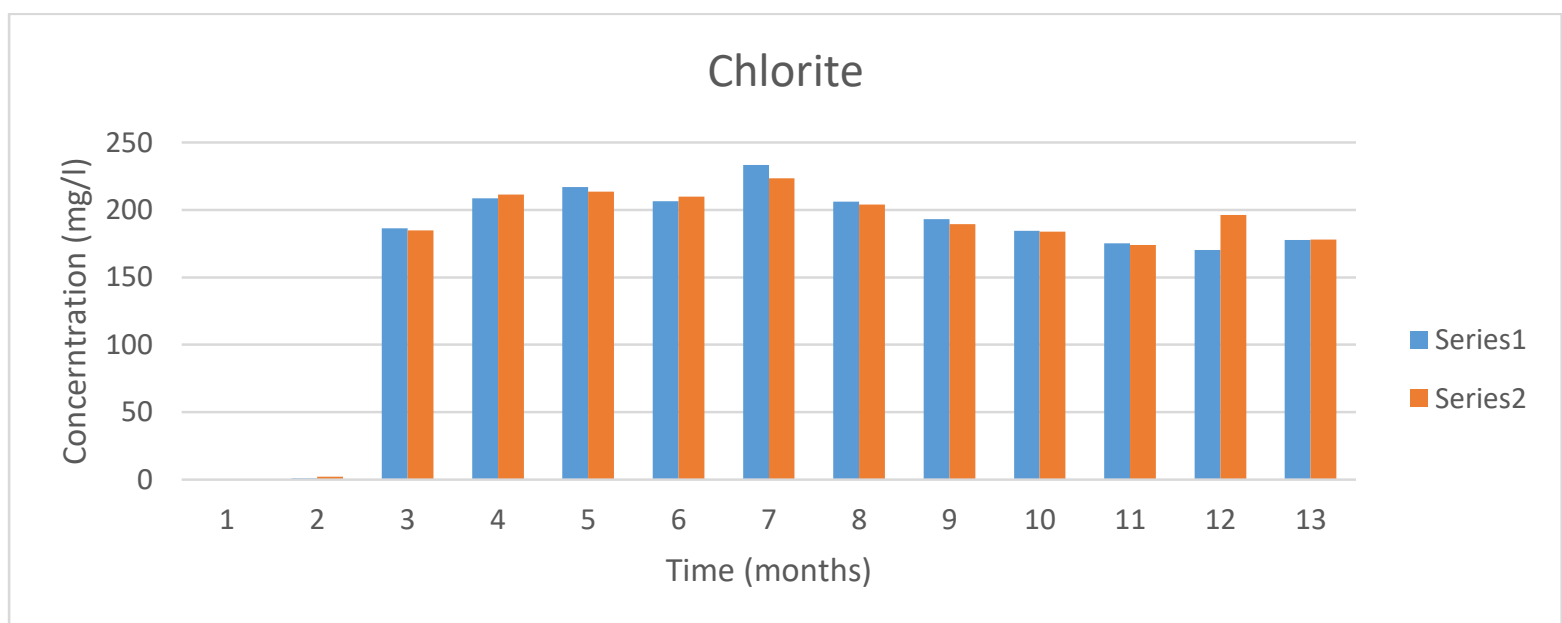

Figure 5: Monthly chlorite discharge concentration 


\section{Nitite}

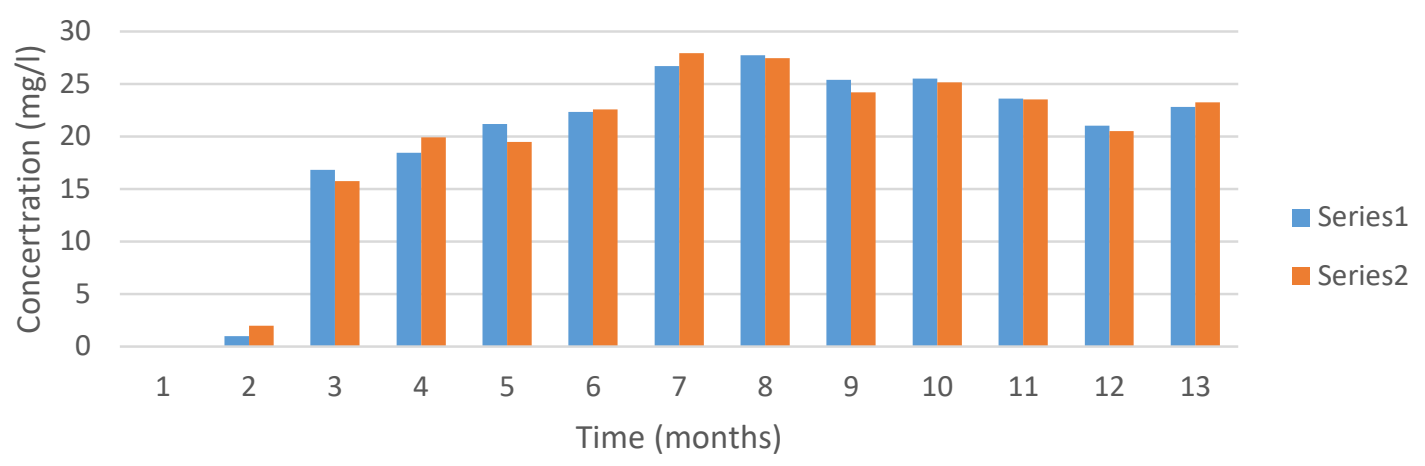

Figure 6: Monthly nitrite discharge concentration

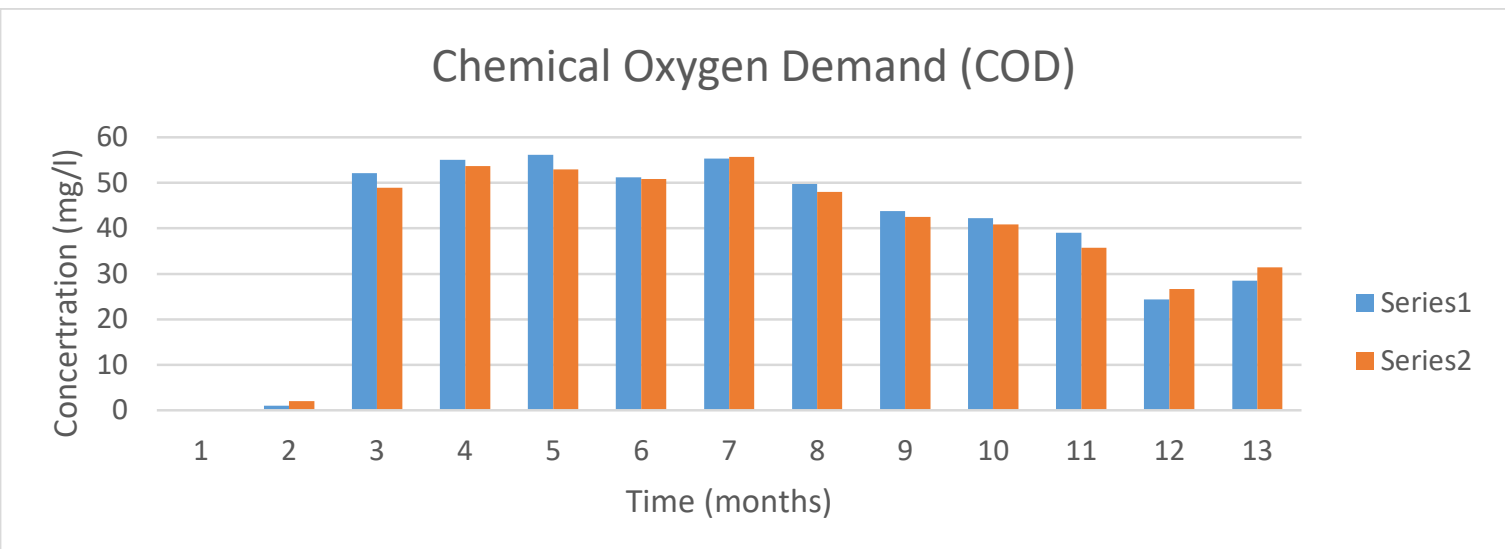

Figure 7: Monthly COD discharge concentration

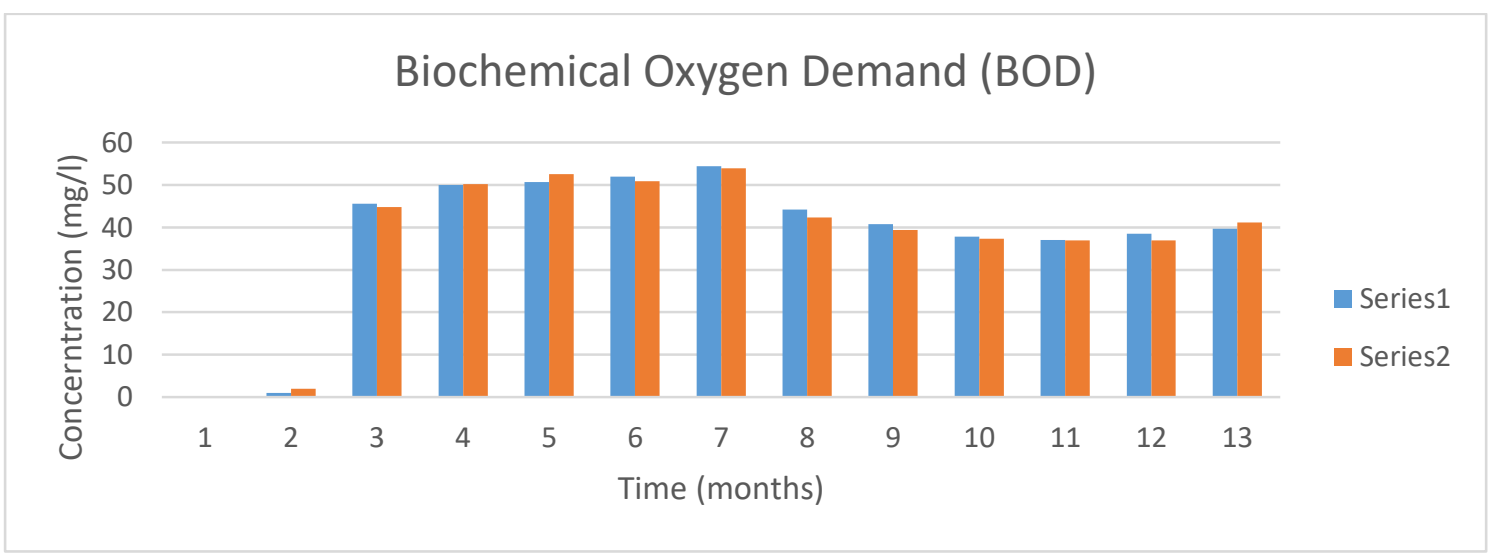

Figure 8: Monthly BOD discharge concentration

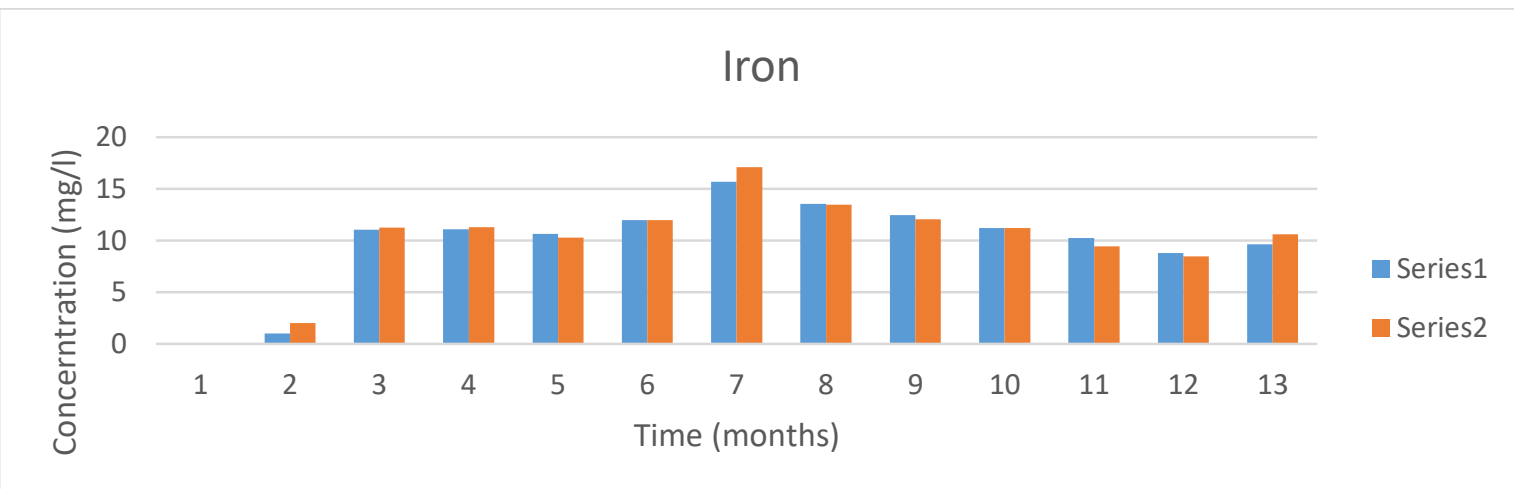

Figure 9: Monthly iron discharge concentration 


\subsection{Discussion}

Results of the analysis are as depicted in Figures $3-9$ for the seven parameters. For each parameter two separate samples were tested each month from January to December as indicated by series 1 and series 2 . In the results for $\mathrm{pH}$, the higher discharge concentration was recorded in February, March and April while the lowest was observed in January. The $\mathrm{pH}$ appears stable for the wet months under review. The stability is optimal for fresh water and can be ascribed to the fact that some portions of the river is on crusted formation and that basic rocks such as limestone contributes to high $\mathrm{pH}$ values.

Dissolved Oxygen concentration recorded higher value in February and then maintains a fairly level value in the wet months. The stability for wet months could be due to the fact that bacteria and others use much of dissolved oxygen for organism under wet weather flows. Chlorite and nitrite recorded higher values in August, possible due to fertilizers used by farmers which are soluble. The COD and BOD appear higher in the month of April through September. This increase is due to waste discharges from domestic drains containing starch, baking soda, carrots, vinegar juice, etc. Iron has a higher concentration in August.

\subsection{Conclusion}

This study was aimed at evaluating the concentrations of seven characteristics of discharges on bimonthly basis as an evidence of organic and inorganic pollutant accumulation into River Kaduna. From the results, the concentration of the seven chemical parameters: $\mathrm{pH}$, dissolved oxygen, chlorite, Chemical oxygen demand, biological oxygen demand and iron, were obtained from effluents and discharges from petrochemical, textile, fertilizer and domestic waste. Table 1 showed the concentration of the parameters while Figures 1 to 7 depicted the change in trends of the concentration of the parameters against time in months.

\section{References}

Arnold, E. G., Lenora, S. C. and Andrew, D. E. (1992). Standard methods for the examination of water and wastewater. American Water Works Association Water Environment Federation, $8^{\text {th }}$ Edition ISBM 0-87553-207-1.

Awale, M. O. and Soubaneh, Y. D. (2004). Wastewater treatment in chemical industries; the concept and current technologies. Hydrology Current Research, 5(1).

Beecroft, G. A. (1986). The treat of pollution to rural water supply. A paper presented at Water Week Celebration. National Water Resources Institute Mando Kaduna Nigeria.

Folorunsho (2000). Assessment of inundation of low lying areas in West Africa. Available at: http://iocunesco.org/component/com.

Garba, H. (2007). Potentials of using immobilized cells of $F$ Oxysporium in the biosorption of heavy metals from textile effluent. MSc Thesis, Ahmadu Bello University, Zaria, Nigeria.

Hanchang, S. H. I. (2013). Point sources of pollution local effects and its control, Industrial Waste water Types. Amounts and Effects. Encyclopedia of Life Support Systems (EOLSS), pp. 191-203.

Islam Mds, and Tanaka, M. (2004). Impact of pollution on coastal and marine ecosystem including coastal and marine fisheries and approach for management: A review and synthesis. Marine pollution Bulletin, 48(7-8), pp. 624-649.

Kaduna State Environmental Protection Agency (2000). Study for the construction of industrial effluent in Kaduna. Vol 1 and 2.

Ludwig, M. and Gould, E. (1998). Contaminant input, fate and biological effect. In: Pacheco, Editor Woods, Hole MA; USA Department of Commerce. NOAA/NMFS/Northeast Fisheries Science Centre NOAA Technical memorandum NMFS/NEC 56, pp. 305-322. 